\title{
Leishmania infection in a population of dogs: an epidemiological investigation relating to visceral leishmaniasis control
}

\author{
Infecção por Leishmania em uma população de cães: uma investigação epidemiológica \\ relacionada ao controle da leishmaniose visceral \\ Klauber Menezes Penaforte'; Vinícius Silva Belo ${ }^{2,3 *}$; Rafael Gonçalves Teixeira-Neto \\ Renata Aparecida Nascimento Ribeiro ${ }^{1}$; Robson Bruniera de Oliveira² ${ }^{2}$; \\ Dante Alighieri Schettini ${ }^{1}$; Eduardo Sergio da Silva ${ }^{1}$
}

\begin{abstract}
${ }^{1}$ Laboratório de Parasitologia, Universidade Federal de São João del Rei - UFSJ, Campus Centro-Oeste Dona Lindu, Divinópolis, MG, Brasil

${ }^{2}$ Departamento de Endemias Samuel Pessoa, Escola Nacional de Saúde Pública Sergio Arouca, Fundação Oswaldo Cruz - Fiocruz, Rio de Janeiro, RJ, Brasil

${ }^{3}$ Departamento de Ciências Básicas da Saúde, Universidade Federal de Juiz de Fora - UFJF, Governador Valadares, MG, Brasil

${ }^{4}$ Laboratório de Leishmanioses, Centro de Pesquisas René Rachou, Fundaçáo Oswaldo Cruz - Fiocruz, Belo Horizonte, MG, Brasil
\end{abstract}

Received March 19, 2013

Accepted October 11, 2013

\begin{abstract}
Identification of factors associated with Leishmania infection in dogs is essential for targeting visceral leishmaniasis control actions. Thus, the present study analyzed some of these factors in a population of dogs in a Brazilian municipality, along with the limitations of control strategies implemented there. The association between the exposure variables and occurrences of infection was analyzed through logistic regression models. The disease control interventions were treated qualitatively. Out of the 755 animals examined, $13.6 \%$ (103/755) were seropositive. Of these, $23.3 \%(24 / 103)$ were asymptomatic and $76.7 \%(79 / 103)$ presented at least one clinical sign possibly associated with visceral leishmaniasis. With weak associations, purebred, shorthaired, over 5 years of age, male and large dogs were more prone to infection. The latter two variables formed the final regression model and the association with dog size was statistically significant. The control strategies developed presented limitations and a great number of seronegative dogs was culled. The data presented contribute towards better understanding of the dynamics of infection in canine visceral leishmaniasis and indicate that actions aimed towards adequate implementation of Visceral Leishmaniasis control program in Brazilian endemic areas should be prioritized.
\end{abstract}

Keywords: Leishmania infantum, risk factors, serology.

\section{Resumo}

A identificação dos fatores associados à infecção por Leishmania em câes é essencial para o direcionamento das açôes de controle da leishmaniose visceral. Desta forma, o presente estudo analisa alguns destes fatores em uma população de cães, bem como as limitaçôes das estratégias de controle executadas em um município brasileiro. Por meio de modelos de regressão logística, analisou-se a associação entre as variáveis de exposição e a ocorrência de infecção. As açóes de controle da doença foram analisadas qualitativamente. Dos 755 animais avaliados por meio de sorologia, 13,6\% (103/755) foram soro-reagentes. Destes, 23,3\% (24/103) eram assintomáticos e 76,7\% (79/103) apresentaram pelo menos um sinal clínico possivelmente associado com a leishmaniose visceral. Com associaçóes fracas, cáes de raça pura, de pelo curto, com mais de cinco anos, machos e de grande porte foram mais propensos à infecçáo. As duas últimas variáveis compuseram o modelo final de regressão, sendo significativa a associação com o tamanho do cão. As estratégias de controle desenvolvidas apresentaram limitaçôes e um número elevado de cáes sorologicamente negativos foi submetido a eutanásia. Os dados apresentados contribuem para um melhor entendimento da dinâmica da infecçáo na leishmaniose visceral canina e indicam que açóes visando a adequada execuçáo do programa de controle da doença em áreas endêmicas brasileiras devem ser priorizadas.

Palavras-chave: Leishmania infantum, fatores de risco, sorologia. 
American visceral leishmaniasis (AVL) is a zoonotic disease in which the etiological agent is the protozoan Leishmania infantum (KUHLS et al., 2011). Domestic dogs are the main reservoir in urban areas of Brazil (BRAGA et al., 1986; GAMA et al., 2004) and the infection is transmitted to humans through the bites of sandflies of the genus Lutzomyia (REITHINGER et al., 2009). Epidemiological, environmental and individual factors associated with canine visceral leishmaniasis (CVL) are not well understood (RONDON et al., 2008).

In the control program of visceral leishmaniasis in Brazil, action directed towards the canine reservoir is restricted to cull seropositive animals, which are identified by conducting sample surveys or censuses. In the Ministry of Health's recommendations, there are no activities directly relating to investigation of potential risk factors associated with the infection in dogs examined (BRASIL, 2006). Given the relevance of such activities for better comprehension of the dynamics of the disease and for defining better target control measures (COURA-VITAL et al., 2011), the importance of this kind of investigation in research and in the routine of the healthcare service is clear.

The present study analyzed factors associated with infection by Leishmania in a population of dogs as well as the limitations of the VL control strategies implemented in a Brazilian municipality.

This cross-sectional study was conducted between March and October 2011. The area studied was the municipality of Divinópolis, which is located in the central-west region of the state of Minas Gerais, Brazil, with a population of approximately 223,000 inhabitants (IBGE, 2013).

Data collection was performed at the Health Surveillance Center of the municipal council (CREVISA). The diagnosis of VL was made in the Parasitology Laboratory of Universidade Federal de São João del Rei, Dona Lindu Central-West Campus. Initially, all animal blood samples were prepared and subjected to the Enzyme-Linked Immunosorbent Assay (ELISA). Those that tested positive or indeterminate were then tested using the Indirect Fluorescent Antibody Test (IFAT) technique. Both tests were performed in accordance with the Bio-Manguinhos/ FIOCRUZ protocol.

A clinical-epidemiological data sheet that covered the exposure variables analyzed in this study (age, sex, breed, type of hair and size), as well as issues relating to the clinical signs presented by the animals and to how the dogs were put down, was developed by the study team together with the CREVISA professionals. The sheets were filled out by the veterinarians at the center, at the time of the consultation or after the neutering. The dogs were culled after authorization was given by the owners or by the citizens who had asked for the stray dogs to be caught. The decision was made and carried out by the veterinarians of CREVISA, based either on clinical signs or on the VL serological findings, and was conducted in accordance with the ethical principles for animal experimentation that have been adopted by the Brazilian College of Animal Experimentation.

Descriptive analyses on the population were carried out, together with evaluation of the most frequent clinical signs in the seropositive animals. Pearson's chi-square test was used to study the associations between the exposure variables and the outcome (positive in both diagnostic techniques or indeterminate result in the ELISA and positive in the IFAT). To describe the force of the associations, the prevalence ratio (PR) was calculated. Logistic regression models were also fitted, using non-automated procedures to select the variables that would form the final model. The age variable was dichotomized using a generalized additive model (HIN et al., 1999). Interaction terms were added to the model and were excluded if they were not statistically significant. Through the modeling, odds ratios and their respective confidence intervals (CI) were obtained for the selected variables. In the initial procedures for defining the inclusion of variables in modeling procedures, $\mathrm{p}$ values $<0.10$ were considered significant. In all the other procedures, $\mathrm{p}$ values $<0.05$ were used. To register the data and statistical analysis, Epi-Info version 3.4.2 and $\mathrm{R}$ version 2.9.2 were used, respectively.

The work at CREVISA was monitored throughout the study period. The completion of the sheets (mentioned above) was confirmed and the performance of control actions recommended by the Brazilian Ministry of Health was analyzed (BRASIL, 2006). To record and analyze the observations, an empirical, qualitative approach was used (LUDKE; ANDRÉ, 1986). This study was submitted to the Animal Research Ethics Committee (CEPEA) of UFSJ and was approved, with protocol number 35/2010.

A total of 755 clinical-epidemiological records were analyzed. Two hundred and twelve dogs $(28.08 \%)$ were seropositive and $32(4.2 \%)$ had indeterminate results in the ELISA. In the IFAT, $57.8 \%(141 / 244)$ presented negative results and 42.2\% (103/244) tested positive. Thus, the prevalence in the canine population studied was $13.6 \%(103 / 755)$.

Regarding the clinical signs of the disease in the seropositive dogs, 23.3\% (24/103) were asymptomatic and 76.7\% (79/103) presented at least one clinical sign possibly associated with VL. Lymphadenopathy, alopecia, weight loss, dermatitis and onychogryphosis were the most frequent (Table 1).

There was a higher prevalence of infections in the following animals: a) of pure breeds ( $\mathrm{PR}=1.15, \mathrm{CI}=0.78-1.69 ; \mathrm{p}=0.55)$; b) with short hair $(P R=1.13, C I=0.70-1.84 ; \mathrm{p}=0.71)$; and

Table 1. Clinical signs observed in 103 dogs seropositive for visceral leishmaniasis, which were evaluated between May and October 2011, in the municipality of Divinópolis, MG, Brazil.

\begin{tabular}{lcc}
\hline \multicolumn{1}{c}{ Clinical sign } & Number of dogs & Frequency \% \\
\hline Low or moderate weight loss & 61 & 59.2 \\
Lymphadenopathy & 59 & 57.3 \\
Opaque or brittle pelage & 56 & 54.4 \\
Onychogryphosis & 40 & 38.8 \\
Skin ulcers & 37 & 35.9 \\
Localized alopecia & 36 & 35.0 \\
Keratoconjunctivitis & 30 & 29.1 \\
Ulcers & 27 & 26.2 \\
Generalized alopecia & 26 & 25.2 \\
Corneal opacification & 18 & 17.5 \\
Cachexy & 11 & 10.7 \\
Neurological complications & 10 & 9.7 \\
Limb edema & 9 & 8.7 \\
\hline
\end{tabular}

$\%$ - percentage. 
c) over five years of age, $(\mathrm{PR}=1.27$ : $\mathrm{CI}=0.84-1.92 ; \mathrm{p}=0.27)$. The final multivariate model was composed of gender and size. Although not statistically significant, male dogs had a higher prevalence of infection $(\mathrm{OR}=1.47 ; \mathrm{CI}=0.98-2.06 ; \mathrm{p}=0.06)$. On the other hand, regarding the size of the animals, there was a statistically significant difference in positivity between small dogs and medium to large-sized dogs $(\mathrm{OR}=1.71 ; \mathrm{CI}=1.14-2.59$; in relation to small dogs, $\mathrm{p}<0.001$ ) (Table 2 ).

Out of the 755 dogs examined, 303 were put down. In 299 cases, the dogs were put down regardless of the serological results (i.e. it was done before serological tests were performed) and only four dogs were culled based on positive serological tests. Therefore, 200 seronegative animals were euthanized using nonstandardized clinical criteria as the justification.

The monitoring of the control activities performed in the municipality revealed that they were being done inadequately. The canine surveys outlined by the Brazilian Ministry of Health (BRASIL, 2006) were not being developed. Thus, only dogs sent to CREVISA due to spontaneous requests from citizens were examined. Moreover, actions targeting priority areas and sandfly vector control initiatives were not being implemented.

Among the population analyzed, $23.3 \%$ were asymptomatic even though they were serologically positive. These data reinforce the importance of these dogs in the epidemiology of the disease and are coincident with those of Feitosa et al. (2000), who reported that $20 \%$ to $40 \%$ of seropositive dogs presented no clinical signs.

Regarding the epidemiological associations studied, the results described are consistent with what has been identified in the literature. Data from a recent systematic review (BELO et al., 2013) showed that the potential risk factors associated with Leishmania infection are generally weak and non-significant. This pattern was confirmed in the present study, since all the associations had small force and operated in the same direction as the meta-analysis conducted in that review.
Concerning the potential mechanisms underlying the direction of the associations observed in the present study and in the review cited above, maintenance of positive findings in serological tests, even for long periods after the infection, may be an important cause of higher prevalence in older dogs (SRIVASTAVA et al., 2011). Furthermore, according to Matos (2006), these animals are usually kept outside the home, which increases the contact with the vector. Although it has been suggested that the prevalence of infection in dogs has bimodal distribution, with one peak among dogs under 3 years of age and another between the ages of 8 and 10 years (MIRÓ et al., 2012), this pattern was not observed in the present study. Although Paltrinieri et al. (2010) pointed out that some breeds are more prone to develop CVL, neither the causes of higher positivity in purebreds nor the specific breeds that are more likely to be infected have been clearly established in the literature (BELO et al., 2013). Regarding the higher prevalence observed in shorthaired dogs, it has been hypothesized that shorter-length fur could facilitate vector feeding, thereby increasing the chance that the dog might contract the infection (MOREIRA-JUNIOR et al., 2003). It is important to emphasize, however, that in the present study such associations were not statistically significant, and the role of chance cannot be ruled out. On the other hand, the association at the threshold of statistical significance between male gender and CVL and the significantly higher prevalence in medium and large-sized dogs, even after controlling for confounding by other study variables in logistic regression models, indicate that these were possibly the most important variables in the population analyzed. There is a possibility that the higher prevalence of infection in males can be explained by the distinct risks of exposure in this group. Immunological factors relating to gender and to the susceptibility to infection have also been discussed in the literature (ZAFRA et al., 2008). The size of the dog as a potential risk factor for CVL has been analyzed in few studies (BELO et al., 2013) and its importance

Table 2. Factors associated with occurrences of visceral leishmaniasis in a population of 755 dogs evaluated between May and October 2011, in the municipality of Divinópolis, MG, Brazil.

\begin{tabular}{|c|c|c|c|c|}
\hline \multirow{2}{*}{ Variable } & \multicolumn{2}{|c|}{ Leishmania serology (\%) } & \multirow{2}{*}{$\begin{array}{c}\text { Measure of association } \\
(95 \% \mathrm{CI})\end{array}$} & \multirow{2}{*}{ p-value } \\
\hline & Positive* & Negative & & \\
\hline \multicolumn{5}{|l|}{ Age $^{a}$} \\
\hline Up to 5 years & $54(12.44)$ & $380(87.56)$ & 1.00 & \\
\hline Over 5 years & $49(15.26)$ & $272(84.74)$ & $1.27(0.84-1.92)$ & 0.266 \\
\hline \multicolumn{5}{|l|}{ Pelage $^{a}$} \\
\hline Long & $17(11.68)$ & $121(88.32)$ & 1.00 & \\
\hline Short & $86(13.94)$ & $531(86.06)$ & $1.13(0.70-1.84)$ & 0.71 \\
\hline \multicolumn{5}{|l|}{ Breed $^{a}$} \\
\hline Pure & $31(15.12)$ & $174(84.88)$ & 1.00 & \\
\hline Undefined & $72(13.09)$ & $478(86.91)$ & $0.87(0.59-1.28)$ & 0.55 \\
\hline \multicolumn{5}{|l|}{ Gender ${ }^{\mathrm{b}}$} \\
\hline Female & $48(11.43)$ & $372(88.57)$ & 1.00 & \\
\hline Male & $55(16.42)$ & $280(83.58)$ & $1.47(0.98-2.06)$ & 0.06 \\
\hline \multicolumn{5}{|l|}{ Size $^{b}$} \\
\hline Small & $28(9.49)$ & $267(90.51)$ & 1.00 & \\
\hline Medium/Large & $75(16.30)$ & $385(83.70)$ & $1.71(1.14-2.59)$ & $<0.001$ \\
\hline
\end{tabular}

${ }^{*}$ Positivity in both serological techniques (ELISA and IFAT); ${ }^{a}$ Results described using Prevalence ratios; ${ }^{\mathrm{b}}$ Results described using Odds ratios; \% - percentage. 
needs to be better evaluated in future investigations. According to Ferrer (1999), larger dogs are more susceptible to the insect vector because they spend more time outside of the home. Furthermore, we hypothesize that the greater body surface area of larger dogs could also be a facilitator for blood meals for sandflies.

It is currently accepted that the scientific evidence available on the efficiency of dog culling for reducing the incidence of zoonotic VL is poor and of low quality (BOUZID et al., 2013). Factors such as the existence of other reservoirs (QUINNELL; COURTENAY, 2009), the low sensitivity and specificity of diagnostic tests (SILVA et al., 2011) and the replacement of eliminated dogs by susceptible puppies (NUNES et al., 2008) can negatively impact the effectiveness of the strategy. The data from the present study relating to dog culling highlight the need for better evaluation of this procedure in this municipality and also in the control program for visceral leishmaniasis in Brazil. Although it is recommended that in areas with moderate or severe transmission, dogs should be put down not only if they are seropositive, but also if they have clinical signs indicative of VL (BRASIL, 2006), there is no clear definition of what these symptoms would be. This lack of definition may lead to application of non-standard and inadequate criteria, similar to what was found in Divinopolis, where a large number of seronegative dogs was inadvertently euthanized. Considering that owners' opposition and ethical issues (COSTA, 2011) are also important reasons for the apparent failure of control by means of dog culling, it cannot be considered acceptable that vague and inconclusive criteria are used to identify dogs that are going to be culled.

Although human cases of VL started to be identified in Divinopolis in 2007, it was found in 2011 (the application period of this study) that the disease control efforts had not followed the recommendations outlined by the Brazilian Ministry of Health. In accordance with the epidemiological pattern of the municipality, canine sampling surveys should have been conducted in areas without human cases and annual census surveys should have been conducted in areas with notified human cases. Because of this limitation, there were no random animal samples and the number of examinations, considering the population of the municipality, was low. Moreover, only variables relating to characteristics of the animals could be analyzed in this study.

Finally, we emphasize that our results contribute towards better understanding of the dynamics of CVL infection and should be taken into consideration in relation to improvement of $\mathrm{VL}$ control strategies in Brazil. The limitations identified in the actions undertaken in Divinopolis highlight not only that there is a need for these to be modified there, but also that the Ministry of Health should undertake supervision of greater thoroughness in endemic municipalities in Brazil, with the aim that its recommendations should be followed appropriately.

\section{Acknowledgements}

The authors wish to thank the staff at CREVISA for their essential cooperation in this study.

\section{References}

Belo VS, Struchiner CJ, Werneck GL, Barbosa DS, Oliveira RB, Teixeira-Neto RG, et al. A systematic review and meta-analysis of the factors associated with Leishmania infantum infection in dogs in Brazil. Vet Parasitol 2013; 195(1-2): 1-13. PMid:23561325. http://dx.doi. org/10.1016/j.vetpar.2013.03.010

Bouzid M, Hooper L, Hunter PR. The effectiveness of public health interventions to reduce the health impact of climate change: a systematic review of systematic reviews. PLoS One 2013; 8(4): e62041. PMid:23634220 PMCid:PMC3636259. http://dx.doi.org/10.1371/ journal.pone.0062041

Braga RR, Lainson R, Shaw JJ, Ryan L, Silveira FT. Leishmaniasis in Brazil. XXII: Characterization of Leishmania from man, dogs and the sandfly Lutzomyia longipalpis (Lutz \& Neiva, 1912) isolated during an outbreak of visceral leishmaniasis in Santarém, Pará State. Trans $R$ Soc Trop Med Hyg 1986; 80(1): 143-145. http://dx.doi.org/10.1016/00359203(86)90214-2

Brasil. Ministério do Saúde. Secretaria de Vigilância em Saúde. Departamento de Vigilância Epidemiológica. Manual de Vigilância e Controle da Leishmaniose Visceral. Brasília: Editora Ministério da Saúde; 2006.

Costa CHN. How effective is dog culling in controlling zoonotic visceral leishmaniasis? A critical evaluation of the science, politics and ethics behind this public health policy. Rev Soc Bras Med Trop, 2011; 44(2): 232-242. PMid:21468480. http://dx.doi. org/10.1590/S0037-86822011005000014

Coura-Vital W, Marques MJ, Veloso VM, Roatt BM, Aguiar-Soares RDO, Reis LES, et al. Prevalence and factors associated with Leishmania infantum infection of dogs from an urban area of Brazil as identified by molecular methods. PLoS Negl Trop Dis 2011; 5(8): e1291. PMid:21858243 PMCid:PMC3156685. http://dx.doi.org/10.1371/ journal.pntd.0001291

Feitosa MM, Ikeda FA, Luvizotto, MCR, Perri SHV. Aspectos clínicos de cães com leishmaniose visceral no município de Araçatuba- São Paulo (Brasil). Clin Vet 2000; 28: 36-44.

Ferrer L. Leishmaniasis. In: Kirk RW, Bonagura JD. Current veterinary therapy: small animal practice. 3rd ed. Philadelphia: W.B. Saunders; 1999. p. 266-270.

Gama MEA, Costa JML, Pereira JCR, Gomes CMC, Corbett CEP. Serum cytokine profile in the subclinical form of visceral leishmaniasis. Braz J Med Biol Res 2004; 37(1): 129-136. PMid:14689054. http:// dx.doi.org/10.1590/S0100-879X2004000100018

Hin L, Lau T, Rogers M, Chang M. Dichotomization of continuous measurements using generalized additive modelling application in predicting intrapartum caesarean delivery. Stat Med 1999; 18(9): 1101-1110. http://dx.doi.org/10.1002/(SICI)10970258(19990515)18:9<1101::AID-SIM99>3.0.CO;2-Q

Instituto Brasileiro de Geografia e Estatística - IBGE [homepage on the Internet] 2013 [cited 2013 Sept 11]. Available from: http://www. ibge. gov.br/cidadesat $/$ xtras/perfil .php? codmun $=312230 \&$ search $=$ minasgerais|divinopolis.

Kuhls K, Alam MZ, Cupolillo E, Ferreira GEM, Mauricio IL, Oddone R, et al. Comparative microsatellite typing of new world Leishmania infantum reveals low heterogeneity among populations and its recent old world origin. PLoS Negl Trop Dis 2011; 5(6): e1155 
PMid:21666787 PMCid:PMC3110170. http://dx.doi.org/10.1371/ journal.pntd.0001155

Ludke M, André MEDA. Pesquisa em educação: abordagens qualitativas. São Paulo: EPU; 1986.

Matos MM, Filgueira KD, Amora SSA, Suassuna ACD, Ahid SMM, Alves ND. Ocorrência da Leishmaniose Visceral em cães em Mossoró, Rio Grande do Norte. Cienc Anim 2006; 16(1): 51-54.

Miró G, Checa R, Montoya A, Hernández L, Dado D, Gálvez R. Current situation of Leishmania infantum infection in shelter dogs in northern Spain. Parasit Vectors 2012; 5: 60. PMid:22452948 PMCid:PMC3348073. http://dx.doi.org/10.1186/1756-3305-5-60

Moreira-Junior ED, Souza VM, Sreenivasan M, Lopes NL, Barreto RB, Carvalho LP. Peridomestic risk factors for canine leishmaniasis in urban dwellings: new findings from a prospective study in Brazil. Am J Trop Med Hyg 2003; 69(4): 393-397.

Nunes CM, Lima VM, Paula HB, Perri SH, Andrade AM, Dias FE, et al. Dog culling and replacement in an area endemic for visceral leishmaniasis in Brazil. Vet Parasitol 2008; 153(1-2): 19-23. PMid:18314275. http:// dx.doi.org/10.1016/j.vetpar.2008.01.005

Paltrinieri S, Solano-Gallego L, Fondati A, Lubas G, Gradoni L, Castagnaro $\mathrm{M}$, et al. Guidelines for diagnosis and clinical classification of leishmaniasis in dogs. J Am Vet Med Assoc 2010; 236(11): 1184-1191. PMid:20513195. http://dx.doi.org/10.2460/javma.236.11.1184
Quinnell RJ, Courtenay O. Transmission, reservoir hosts and control of zoonotic visceral leishmaniasis. Parasitology 2009; 136(14): 1915-1934. PMid:19835643. http://dx.doi.org/10.1017/S0031182009991156

Reithinger R, Brooker S, Kolaczinski JH. Visceral leishmaniasis: time to better use existing resources. Lancet 2009; 17; 374(9698): 1330.

Rondon FC, Bevilaqua CM, Franke CR, Barros RS, Oliveira FR, Alcântara AC, et al. Cross-sectional serological study of canine Leishmania infection in Fortaleza, Ceará state, Brazil. Vet Parasitol 2008; 155(1-2): 24-31. PMid:18565676. http://dx.doi.org/10.1016/j.vetpar.2008.04.014

Silva DA, Madeira MF, Teixeira AC, de Souza CM, Figueiredo FB. Laboratory tests performed on Leishmania seroreactive dogs euthanized by the leishmaniasis control program. Vet Parasitol 2011; 179(1-3): $257-$ 261. PMid:21349644. http://dx.doi.org/10.1016/j.vetpar.2011.01.048

Srivastava P, Dayama A, Mehrotra S, Sundar S. Diagnosis of visceral leishmaniasis. Trans $R$ Soc Trop Med Hyg 2011; 105(1): 1-6. PMid:21074233 PMCid:PMC2999003. http://dx.doi.org/10.1016/j. trstmh.2010.09.006

Zafra R, Jaber JR, Pérez-Ecija RA, Barragán A, Martínez-Moreno A, Pérez J. High iNOS expression in macrophages in canine leishmaniasis is associated with low intracellular parasite burden. Vet Immunol Immunopathol 2008; 123(3-4):353-359. PMid:18406470. http://dx.doi. org/10.1016/j.vetimm.2008.02.022 